\title{
Susceptibility of two spotted spider mite Tetranychus urticae KOCH (Acari; Tetranychidae) to some selected miticides in the Greater Accra Region of Ghana
}

\author{
V.Y. EZIAH ${ }^{1 *}$, R.B. BUBA ${ }^{2}$ and K. AFREH-NUAMAH ${ }^{3}$ \\ ${ }^{I}$ Department of Crop Science, P. O. Box LG 44, University of Ghana, Legon. \\ ${ }^{2}$ Clo L.C.C.N No. 1 Mayo-gwoi, P. O. Box 288, Jalingo, Nigeria. \\ ${ }^{3}$ African Regional Postgraduate Programme in Insect Science (ARPPIS), University of Ghana. \\ "Corresponding author; E-mail: eziahvin@yahoo.com
}

\begin{abstract}
The two-spotted spider mite Tetranychus urticae is a serious pest of vegetables, fruits and field crops in Ghana but hardly noticed by farmers. A recent survey in parts of Greater Accra Region revealed that farmers do not specifically target $T$. urticae in terms of control but use insecticides at high dosages and at short intervals to address the complex of pest affecting their crops. This practice is a recipe for resistance development in mite pest. Susceptibility studies were carried out using five miticides, lambda cyhalothrin, emamectin benzoate, prosular oxymatrine, imidacloprid and sulphur. Adult T. urticae were collected from four suburbs in Accra (Opeibea, Ashaiman, University of Ghana Farm and Department of Crop Science Sinna Garden). These populations were used to raise colonies on garden egg plants in separate laboratories. Infested leaves were taken from the plants and sprayed with serial dilutions of the miticides and mortality recorded after $24 \mathrm{~h}$. The $\mathrm{LD}_{50}$ values and slopes were determined using probit analysis and resistance factors calculated. All field populations were quite resistant to Karate ${ }^{\circledR}$ (up to 21.6-fold) but were susceptible to the other four products where resistance factors were quite low. The University of Ghana Farms, Sinna Garden and Ashaiman populations were susceptible to Imidacloprid except the Opeibea population which showed a low level of resistance (9-fold). Synergism assays using piperonyl butoxide $(0.4 \mu \mathrm{L} / \mathrm{mL})$ and Diethyl maleate $(1.0 \mu \mathrm{L} / \mathrm{mL})$ on the Karate ${ }^{\circledR}$-resistant population showed that the application of these products $1 \mathrm{~h}$ before treatment with Karate $^{\mathbb{B}}$ reduce resistance in the Opeibea population from 21-fold to between 2.9 to 4.3 -fold whereas that of Ashaiman was reduced from 19-fold to 2.6-fold suggesting the involvement of glutathione-S-tranferases (GSTs) and cytochrome P450 monooxygenases and esterases as the possible mechanisms of resistance.
\end{abstract}

(C) 2016 International Formulae Group. All rights reserved.

Keywords: Tetranychus urticea, resistance, glutathione-S-tranferases, cytochrome P450 monooxygenases, esterases, piperonyl butoxide, diethyl maleate.

\section{INTRODUCTION}

The two-spotted spider mite

Tetranychus urticae Koch (Acari:
Tetranychidae) is the most economically important plant-feeding mite pest in the world (Van Leeuwen et al., 2012). It is a 
cosmopolitan and highly polyphagous pest of many fruits, vegetables, ornamentals, and field crops. Tetranychus urticae threatens greenhouse production and field, vine, and orchard crops, destroying economically important annual and perennial crops such as leafy greens, cotton, green beans, and soybeans, among others (Gallo et al., 2002). Spider mites damage their host plants while feeding, thereby removing chlorophyll and other cell contents. The loss of chlorophyll results in a visibly patchy discoloration of leaf tissue, as well as a reduced photosynthetic rate and production of nutrients (Park and Lee, 2002).

Acaricide resistance in $T$. urticae has been reported from over 60 countries (DARP, 2013) easily earning it the title of the world's top resistant animal pest (Van Leeuwan et al., 2010). The development of resistance in $T$. urticae has been reported for a number of compounds, including organophosphates, clofentezine, hexythiazox, bifenthrin, fenpropathrin, bifenazate, fenpyroximate, pyridaben, tebufenpyrab, chlorfenapyr, etoxazole, spirodiclofen, abamectin, and milbemectin (Osakabe et al., 2009; Van Leeuwen et al., 2010). Efforts to manage $T$. urticae populations in field crops rely on the use of acaricides. Although acaricides have proven to be highly effective in protecting crops under extreme pressure from pest (Cooper and Dobson, 2007), the over reliance on synthetic chemicals in crop cultivation has generally caused mite resistance development and public concerns on their high residues in crop, soils and water (Owusu and Yeboah, 2007) as well as adverse effects on nontargeted beneficial organism, and therefore there is a need for monitoring of $T$. urticae population. Although farmers have reported of the lack of control using conventional mititicides, little or no studies have been done to ascertain this in Ghana. It is, therefore, necessary to conduct susceptibility test to determine the resistance levels if any of these pest to commonly used miticides so that potential solutions can be developed before the onset of severe economic losses to growers. The early detection of resistance aids in better resistance management and in reducing resistance related cost to farmers. This paper reports the susceptibility of four field populations of the two-spotted spider mite to five miticides in the Greater Accra Region of Ghana. Experiments using synergist, piperonyl butoxide (PBO) and diethyl maleate (DEM) were also carried out to determine the possible role of detoxifying enzymes in resistance in spider mite.

\section{MATERIALS AND METHODS}

\section{Study area}

The study was conducted in four localities within Accra metropolis (Ashaiman, Opeibea, Department of Crop Science Sinna Garden and University of Ghana Farm, Legon) (Figure 1). These areas were chosen because of the differences in farming practices, rainfall and pesticide usage pattern. The Accra metropolitan area is located within the Greater Accra Region in Southern Ghana. It is a coastal savannah ecological zone characterized by dry climatic conditions with two peak rainy seasons from April to June and September to October. The annual rainfall ranges between 740 and $890 \mathrm{~mm}$ per annum, temperature of $26{ }^{\circ} \mathrm{C}$ to $30{ }^{\circ} \mathrm{C}$ and relative humidity of $65 \%$ to $75 \%$ (www.meteo.gov.gh, accessed in March 2015).

\section{Miticides}

Commercial formulations of miticide tested were Karate $^{\circledR}$ (lamda-cyhalothrin 5\% EC Syngenta Crop Protection Pty Ltd, Pendle Hill, NSW), Protect ${ }^{\circledR}$ (Emamectin Benzoate 1.9\% EC Syngenta Crop Protection Pty Ltd, Pendle Hill, NSW), Levo ${ }^{\circledR} 2.4$ SL $^{\text {TM }}$ Sineria Industries Ltd. Neosytou Georgiou, The Netherlands), Anty ataa ${ }^{\circledR}$ (Imidacloprid Bayer 
Australia Ltd, Pymble, NSW) and the synergists piperonyl butoxide (PBO) $(97.5 \%$ ultra PBO, Pu-SF-02-008, Endura ${ }^{\circledR}$ Fine Chemicals, Italy) and diethyl maleate (DEM) 97\% (Aldrich Chemical Company, Inc., Milwuakee, USA).

\section{Field Sampling of spider mites}

Adult T. urticae were collected between November 2014 and April 2015, from commercial Eggplants, Okra, Pawpaw and Cassava farms established at the aforementioned locations. The susceptible population were collected from infested cassava plants grown in the screen house of the Department of Crop Science, University of Ghana where miticides had not been used for well over five years. Populations from these locations were established on garden egg Solanum integrifolium plants in different laboratories. The third and fourth generations were then used for laboratory bioassays.

\section{Bioassay}

The leaf disc bioassays described by Piraneo (2013) was employed to determine the efficacy of the miticides against the mites. Five serial dilutions of each miticide were prepared in distilled water. Infested leaves were cut into discs and placed in a $90 \mathrm{~mm}$ petri-dish lined with filter paper. The number of mites on each leaf disc was then counted under a microscope and recorded. The leaves were then sprayed with $1 \mathrm{~mL}$ of each miticide dilution using a hand sprayer. The control treatments were sprayed with distilled water only. There were three replications per concentration. All treatments were maintained at $27.0 \pm 2.0{ }^{\circ} \mathrm{C}$ and $65.0 \pm 5 \%$ with a photoperiod of $12 \mathrm{~h}: 12 \mathrm{~h}$ (L: D). Mortality was assessed $24 \mathrm{~h}$ and mites were considered dead if they were twitching or were unable to move a distance equivalent to their body length when prodded with a blunt probe under the microscope.

\section{Time series experiment for PBO and DEM} synergists

The Karate ${ }^{\circledR}$-resistant Opeibea and Ashaiman populations were used to determine the optimal (non-lethal) PBO and DEM concentrations (data not provided). A time series experiment was carried out with PBO and DEM to determine the optimum time lapse between synergist and miticide application. Infested leaves were cut into leaf discs and placed in a $90 \mathrm{~mm}$ petri dish lined with filter paper and pre-treated with nonlethal concentrations of PBO $(0.4 \mu \mathrm{L} / \mathrm{mL})$ and DEM $(1.0 \mu \mathrm{L} / \mathrm{mL})$ determined from above. Karate ${ }^{\circledR}$ miticide at 0.15 and $0.14 \mathrm{~mL} / \mathrm{L}$ which produced $50 \%$ mortality in the Opeibea and Ashaiman populations, respectively was then sprayed on the mites at $0,1,2$ and $3 \mathrm{~h}$ after pre-treatment with the synergists. There were three replicate Petri dishes each per treatment. The experimental conditions were the same as before and mortality was recorded as stated earlier.

\section{Synergism assays}

The optimal PBO and DEM concentrations determined from the above experiments were used for the assays. Infested leaves which were cut into leaf discs were pre-treated with $0.4 \mu \mathrm{L} / \mathrm{mL}$ and $1.0 \mu \mathrm{L} / \mathrm{mL}$ $\mathrm{PBO}$ and DEM, respectively. Five concentrations of Karate $^{\circledR}$ miticide were serially diluted and sprayed on each leaf disc $1 \mathrm{~h}$ after treatment with the synergists. Each treatment was replicated three times. The experimental conditions were the same as before and mortality was recorded as stated earlier.

\section{Data analysis}

Mortality data were subjected to probit analysis (Finney, 1971) using a US Environmental Protection Agency probit program version 1.5 to determine the $\mathrm{LD}_{50}$, slope and fiducial limits. Resistance factors 
(RFs) were determined by dividing the $\mathrm{LD}_{50}$ of the field populations by the $\mathrm{LD}_{50}$ of the susceptible population. Time-series experiments were analysed using analysis of variance (ANOVA) after the percentage mortalities were arcsine transformed. The means were separated using the least significant difference (LSD). The synergist ratio (SR) was determined by dividing the $\mathrm{LD}_{50}$ of the field population without synergists by the $\mathrm{LD}_{50}$ of the field population with synergists.

\section{RESULTS}

The response pattern of the two-spotted spider mite to the five miticides showed differences in susceptibility among the four field populations (Table 1). The $\mathrm{LD}_{50}$ values of all field population were higher than those of the susceptible strain for the five miticides assayed. Resistance of the field populations to Protect $^{\circledR}$ was quite high ranging from 7.011.0-fold compared to the susceptible population. All field populations were resistant to Karate ${ }^{\circledR}$ (ranging from 12.0-21.6fold) differing significantly from the reference strain but not amongst each other. The field population showed differences in response to Imidacloprid insecticide. The Opeibea population recorded the highest resistance (9.0-fold) to Imidacloprid but did not differ significantly from the other populations including the susceptible strain. However, all the field populations were susceptible to Levo $^{\circledR}$, one of the 'newer' insecticides on the Ghanaian market and Sulphur $^{\circledR}$ (except Opeibea population with 11.0-fold resistance) as there were no significant differences amongst the field populations. The slopes of the response curves for all the five miticides were low ranging from $0.57-1.12$. Thus indicating the heterogeneity in the response of the field populations' to the miticides.

The optimal PBO and DEM concentrations were 0.4 and $1.0 \mu \mathrm{L} / \mathrm{mL}$ for the Karate ${ }^{\circledR}$-resistant population, respectively. Time series experiment showed significant differences $(\mathrm{P}<0.05)$ between mortalities in mites exposed immediately to Karate ${ }^{\circledR}$ after pre-treatment with PBO and DEM and those with the insecticide 1 or $2 \mathrm{~h}$ later (Table 2). The synergism assay also showed that both PBO and DEM significantly reduced the susceptibility of the Karate $^{\circledR}$-resistant population of Opeibea from 21.0-fold to between 4.3-2.9-folds and Ashaiman from 19.0-fold to about 2.6-fold, respectively (Table 3).

Table 1: Response of four field populations of $T$. urticea to five miticides by spray application.

\begin{tabular}{lccccc}
\hline Miticide / population & $\mathbf{N}$ & $\mathbf{L D}_{\mathbf{5 0}}$ & $\mathbf{9 5 \%}$ FL & Slope \pm SE & RF \\
\hline Protect $^{\circledR}$ & & & & & \\
Susceptible & 150 & 0.001 & $0.000-0.004$ & $0.749-0.177$ & - \\
Opeibea & 207 & 0.007 & $0.002-0.017$ & $0.859 \pm 0.159$ & 7.0 \\
Sinna Garden & 258 & 0.007 & $0.002-0.018$ & $0.772 \pm 0.123$ & 7.0 \\
Ashaiman & 192 & 0.011 & $0.002-0.036$ & $0.587-0.105$ & 11.0 \\
UG Farm & 186 & 0.008 & $0.002-0.024$ & $0.567-0.106$ & 8.0 \\
& & & & & \\
Imidacloprid & & & & & \\
Susceptible & 150 & 0.008 & $0.002-0.023$ & $0.766-0.153$ & - \\
Opeibea & 261 & 0.072 & $0.011-0.219$ & $0.700-0.146$ & 9.0 \\
Sinna Garden & 309 & 0.022 & $0.006-0.056$ & $0.660-0.096$ & 2.8 \\
Ashaiman & 192 & 0.014 & $0.004-0.013$ & $0.857-0.129$ & 1.8 \\
UG Farm & 252 & 0.055 & $0.016-0.123$ & $0.754-0.120$ & 6.9 \\
& & & & &
\end{tabular}




\begin{tabular}{lccccc}
\hline Karate $^{\circledR}$ & & & & & \\
Susceptible & 150 & 0.007 & $0.001-0.023$ & $0.646-0.143$ & - \\
Opeibea & 273 & 0.151 & $0.038-0.375$ & $0.793-0.137$ & 21.6 \\
Sinna Garden & 222 & 0.094 & $0.025-0.242$ & $0.680-0.118$ & 13.4 \\
Ashaiman & 225 & 0.139 & $0.036-0.333$ & $0.761-0.131$ & 19.9 \\
UG Farm & 216 & 0.084 & $0.034-0.175$ & $0.790-0.119$ & 12.0 \\
& & & & & \\
Levo & & & & & \\
Susceptible & 150 & 0.003 & $0.001-0.009$ & $0.748-0.147$ & - \\
Opeibea & 150 & 0.012 & $0.003-0.028$ & $1.115-0.262$ & 4.0 \\
Sinna Garden & 183 & 0.007 & $0.002-0.021$ & $0.648-0.127$ & 2.3 \\
Ashaiman & 282 & 0.006 & $0.002-0.013$ & $0.762-0.118$ & 2.0 \\
UG Farm & 213 & 0.009 & $0.001-0.005$ & $0.658-0.105$ & 3.0 \\
& & & & & \\
Sulphur & & & & & \\
Susceptible & 150 & 0.003 & $0.000-0.011$ & $0.633-0.141$ & - \\
Opeibea & 150 & 0.033 & $0.799-0.123$ & $0.009-0.176$ & 11.0 \\
Sinna Garden & 228 & 0.017 & $0.002-0.020$ & $0.584-0.097$ & 5.7 \\
Ashaiman & 297 & 0.013 & $0.005-0.025$ & $0.911-0.128$ & 4.3 \\
UG Farm & 249 & 0.02 & $0.006-0.047$ & $0.644-0.108$ & 6.7 \\
\hline
\end{tabular}

$\mathrm{N}$, total number of mites tested; FL, fiducial limits; RF, resistance factor $=\mathrm{LD}_{50}$ field population $/ \mathrm{LD}_{50}$ susceptible strain; $\mathrm{LD}_{50}=$ dose required to kill $50 \%$ of the population; SE, standard error;

Table 2: Time-series experiments using $\operatorname{Karate}^{\circledR}$-resistant population.

\begin{tabular}{llll}
\hline Population & Insecticide/synergist concentration & Time (h) & Mean \pm SE \% mortality \\
\hline Opeibea area & $0.151 \mathrm{~mL} / \mathrm{L}+0.4 \mu \mathrm{L} / \mathrm{mL}(\mathrm{PBO})$ & 0 & $48.9 \pm 3.22 \mathrm{a}^{\mathrm{a}}$ \\
& & 1 & $94.8 \pm 2.60^{\mathrm{b}}$ \\
& & 2 & $83.2 \pm 4.10^{\mathrm{bc}}$ \\
Opeibea area & $0.151 \mathrm{~mL} / \mathrm{L}+1.0 \mu \mathrm{L} / \mathrm{mL}(\mathrm{DEM})$ & 3 & $79.5 \pm 3.61^{\mathrm{c}}$ \\
& & 1 & $48.7 \pm 1.28^{\mathrm{a}}$ \\
& & 2 & $88.2 \pm 6.05^{\mathrm{b}}$ \\
Ashaiman & $0.139 \mathrm{~mL} / \mathrm{L}+0.4 \mu \mathrm{L} / \mathrm{mL}(\mathrm{PBO})$ & 0 & $76.7 \pm 3.40^{\mathrm{bc}}$ \\
& & 1 & $50.0 \pm 1.90^{\mathrm{c}}$ \\
& & 2 & $94.7 \pm 2.68^{\mathrm{bc}}$ \\
\multirow{4}{*}{ Ashaiman } & $0.139 \mathrm{~mL} / \mathrm{L}+1.0 \mu \mathrm{L} / \mathrm{mL}(\mathrm{DEM})$ & 0 & $81.4 \pm 9.44^{\mathrm{c}}$ \\
& & 1 & $68.5 \pm 5.69^{\mathrm{ac}}$ \\
& & 2 & $63.2 \pm 4.30^{\mathrm{a}}$ \\
& & 3 & $62.34 \pm 2.52^{\mathrm{bc}}$ \\
\hline
\end{tabular}

Means followed by the same letter do not differ significantly $(P=0.05)$ from one another. PBO, piperonyl butoxide; DEM, diethyl maleate; SE, standard error. 
Table 3: Response of T. urticae to Karate ${ }^{\circledR}$-resistant populations pre-treated $1 \mathrm{~h}$ with Synergist.

\begin{tabular}{lccccl}
\hline Population & N & LD $_{\mathbf{5 0}}$ & $\mathbf{9 5 \%}$ FL & Slope \pm SE & SR \\
\hline Opeibea & 273 & 0.151 & $0.038-0.375$ & $0.793 \pm 0.137$ & 21.6 \\
Opeibea + PBO & 150 & 0.035 & $0.007-0.105$ & $0.748 \pm 0.127$ & 4.3 \\
Opeibea+ DEM & 150 & 0.053 & $0.018-0.107$ & $0.601 \pm 0.107$ & 2.9 \\
& & & & & \\
Ashaiman & 225 & 0.139 & $0.036-0.333$ & $0.761 \pm 0.131$ & 19.9 \\
Ashaiman+PBO & 150 & 0.062 & $0.012-0.121$ & $0.436 \pm 0.238$ & 2.2 \\
Ashaiman+DEM & 150 & 0.053 & $0.007-0.209$ & $0.704 \pm 0.089$ & 2.6 \\
\hline
\end{tabular}

$\mathrm{N}$, total number of mites tested; FL, fiducial limits; SR, synergist ratio $=\mathrm{LD}_{50}$ of field population without synergist/LD $/ \mathrm{D}_{50}$ of field population with synergist. $\mathrm{LD}_{50}=$ dose required to kill $50 \%$ of the population; SE, standard error;

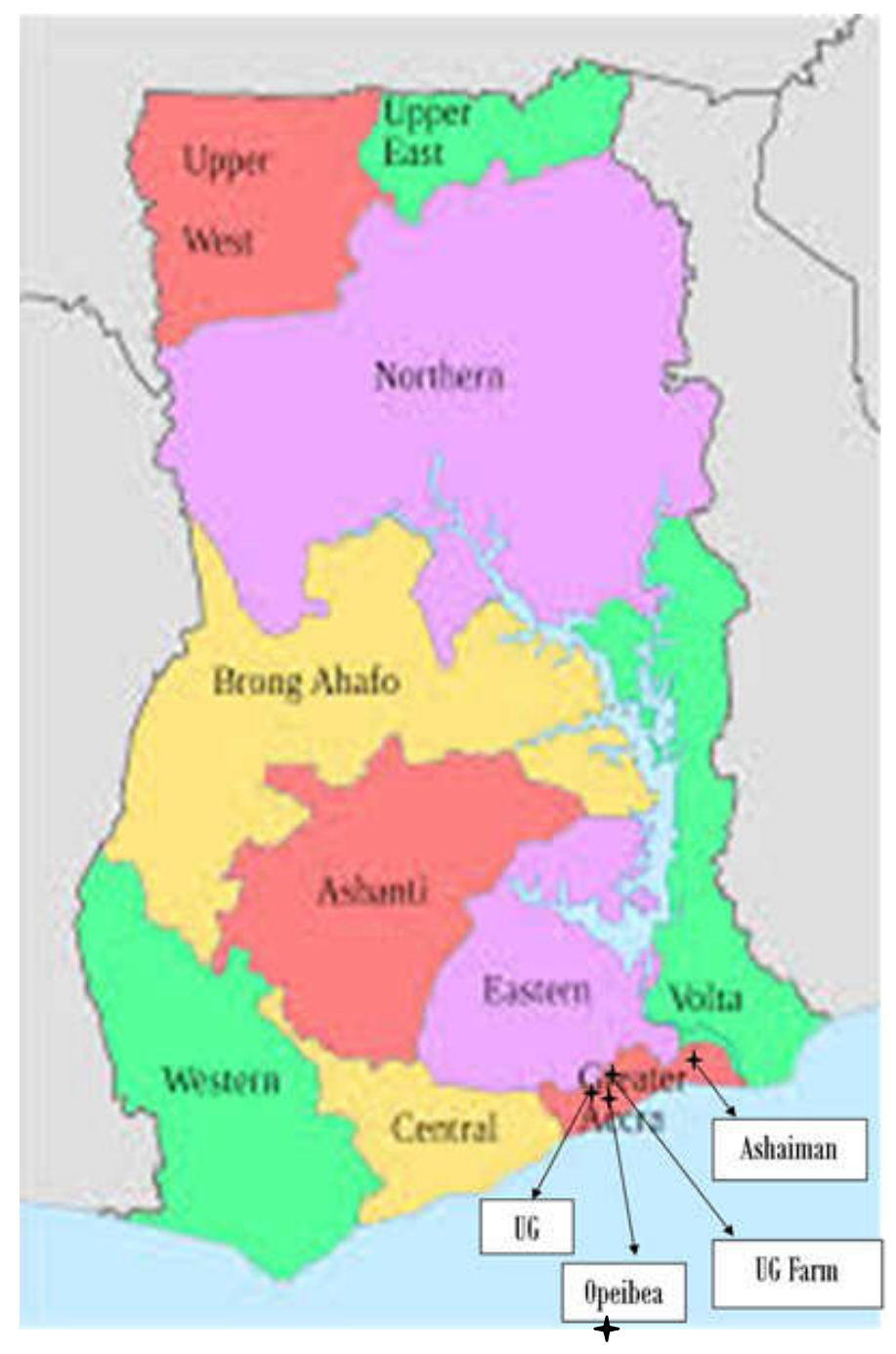

Figure 1: Map of Ghana indicating sites where mites were collected. UG $=$ University of Ghana, UG Farm = University of Ghana Farm, Legon . 


\section{DISCUSSION}

The level of resistance observed in all field populations to Karate $^{\circledR}$ indicates the extent to which this product has been used to control pest in these areas. The commercial farms in this study (Opeibea and Ashaiman) recorded the highest $\mathrm{LD}_{50}$ values of 0.15 and $0.14 \mathrm{~mL} / \mathrm{L}$ corresponding to a 21.6 -fold and 19.9-fold resistance, respectively. Also up to 13-fold resistance was observed in mite populations from the University of Ghana Farm and Sinna Garden. Yang et al. (2002) have reported 9.5-fold and 51.8-fold resistance to bifenthrin and lambda cyhalothrin respectively in Kansas population of T. urticae. The authors stated that there is a risk of cross resistance between bifenthrin and lambda cyhalothrin and also between bifenthrin and dimethoate as selection with dimethoate led to a 15.9-fold cross resistance to bifenthrin. Selection with lambda cyhalothrin also led to a 2.8-fold cross resistance to bifenthrin. Wintuma (2009) and Kingsley (2010) have reported high resistance of field populations of diamondback moth and whiteflies to Karate ${ }^{\circledR}$ from these two locations (Opeibea and Ashaiman). Agbovi et al. (2015) reported that despite the continued use of synthetic insecticides particularly organophosphates and synthetic pyrethroids in vegetable crop production in Togo insects continue to cause serious damage to crops

Though the susceptibility level of the mite to Karate $^{\circledR}$ appears to be low, some farmers claimed the product was effective in the control of the pest. This is significant considering that these fields have continually been exposed to this product for the past 6 years. Therefore, there is a need to discourage the use of synthetic pyrethroids in pest control in these areas so as not to worsen the resistance problem (Queiroz and Sato, 2016). It should be noted that $T$. urticae develops resistance to chemical groups after few years of use which makes its control very difficult (DARP, 2013).

The current studies showed that all the population were susceptible to Protect $^{\circledR}$ (Emamectin benzoate). The $\mathrm{LD}_{50}$ values ranged from $0.007-0.011 \mathrm{~mL} / \mathrm{L}$ and resistance ratios ranged from 7.0-11.0 fold. These findings are not unexpected as the product has only been recently introduced into the Ghanaian market for the management of vegetable pests. High susceptibility of field populations of mites to abamectin has been reported in other studies. While Fahnbulleh (2007) reported only a 1.10 to 1.31 - fold toxicity in Norwegian populations of $T$. urticae. Sokeli et al. (2007) reported up to 1.6fold toxicity in populations in Isparta Province. The presence of abamectin and emamectin benzoate (avermectins) reservoirs in parenchyma tissue accounts for their long residual activity on certain crops under field conditions, and their ability to control several Lepidoptera (Ishaaya et al., 2002).

Piraneo et al. (2015) reported a decreased activity of abamectin in T. urticae while monitoring hopyards in Pacific Northwest states. Resistance ratios ranged from 1.5-100-fold. The authors attributed the high level of resistance to the widespread use of abamectin in the area. Vassilious and Kitsin (2013) reported 1356-fold resistance to abamectin in greenhouse from Cyprus. Tetranychus urticae have been found to develop cross-resistance to other chemical groups. Sato et al. (2005) reported that $T$. urticae developed 342-fold resistance to abamectin after 5 selections and also showed a cross-resistance to milbemectin (16.3-fold) and chlorfenapyr (2.3-fold). The foregoing indicates that farmers in Ghana ought to be educated in the use of this product for mite control considering the levels of resistance reported elsewhere after a few years of continues use. 
Tetranychus urticae population from all the fields were susceptible to imidacloprid except Opeibea population which recorded a 9.0-fold resistance. Curé et al. (2001) reported that at very low doses imidacloprid may not cause death of honey bees but can induce decreased foraging activity. James and Price (2002) have also reported an increase in egg production of female T.urticae by $26 \%$ after 12 days of adult life by spray application with Imidacloprid. Imidacloprid is a new introduction into the Ghanaian market; therefore, it is not surprising the level of susceptibility to this product observed in these vegetable growing areas. The application of this product on need basis could help maintain its efficacy for field protection against mites for quite some time.

Oxymatrine and oxymatrine-based products have shown considerable toxic and anti-feedant activity against several pest species in laboratory bioassays (Mao and Henderson, 2007; Asghari-Tabali et al. 2007). Spider mite populations from all the four farms were highly susceptible to levo ${ }^{\circledR}$ (Prosular oxymatrine). The $\mathrm{LD}_{50}$ values ranged from 0.006 to 0.012 . Wang et al. (2009) found the combination of oxymatrine/prosular to have an $\mathrm{LC}_{50}$ of 150 $\mu \mathrm{g} / \mathrm{L}$ for carmine spider mites $T$. cinnabarinus. Marcic and Medo (2014) reported an $\mathrm{LC}_{50}$ value of $14.8 \mu \mathrm{L} / \mathrm{L}$ after 96 $\mathrm{h}$. The authors also stated that $24 \mathrm{~h}$ exposure to prosular oxymatrine at the concentration of $34.3 \mu \mathrm{L} / \mathrm{L}$ caused a corrected mortality of $60 \%$ and reduced net fertility of the surviving females by $90 \%$. The use of this insecticide is not widespread in Ghana from a survey conducted by this author during this studies (data not provided) thus the high susceptibility levels. Therefore, there is a need to monitor its use to delay resistance development in the future.

Sulphur is one of the oldest known insecticides used for the control or prevention of black spot, rust, leaf rust and powdery mildew on ornamentals, fruits and vegetables. It is also less frequently used as miticide. In the present study resistance in the field populations ranged between 4.3-11-fold compared to the control. This may probably be due to the fact that Sulphur ${ }^{\mathbb{R}}$ is only recently being used for mite control. In laboratory experiments Auger et al. (2003) reported that susceptibility of $T$. urticea to wettable sulphur was influenced by temperature and relative humidity at $27.5^{\circ} \mathrm{C}$ and $75 \% \mathrm{RH}$, respectively. The authors indicated that beyond this threshold, the acaricidal effect increases with rising temperature or humidity, to become complete at a temperature of $35{ }^{\circ} \mathrm{C}$ and $90 \% \mathrm{Rh}$. The use of sulphur in pest management programmes may help keep mite populations below economic injury level.

Synergism of Karate $^{\circledR}$ by PBO and DEM resulted in increased toxicity of Opeibea and Ashaiman populations, respectively and required $1 \mathrm{~h}$ pre-treatment period. Resistance ratios decreased from 21.6 to between 2.9 and 4.3 for DEM and PBO, respectively in the Opeibea population whilst that of Ashaiman dropped from 19-fold to about 2-fold. Pasay et al. (2008) have shown in laboratory experiments that the application of $\mathrm{PBO} /$ permethrin drastically reduced the median survival time of permethrin-resistant Sarcoptes scabiei variety Canis from 15 to 4 hours. Eziah et al. (2008) have shown a 30fold and 1.9-fold synergist ratio using $\mathrm{PBO}$ and DEM in Esfenveralate-resistant populations of DBM showing a 300 and 490fold resistance, respectively. These results are consistent with those obtained in the current study and suggest the involvement of glutathione-S-tranferases and cytochrome P450 monooxygenases in the observed resistance to $\operatorname{Karate}^{\circledR}$ in these locations.

The present study revealed that all field populations of spider mites were susceptible 
to all miticides tested except Karate ${ }^{\circledR}$. These provide the basis for resistance monitoring in spider mite populations in the future. The study also showed that both PBO and DEM might be helpful in the management of resistance of spider mite to Karate $^{\circledR}$ insecticide. Education of farmers on judicious use of the 'newer' products in vegetable pests management is equally important so as to maintain the efficacy of the products.

\section{COMPETING INTERESTS}

The authors declare that they have no competing interests.

\section{AUTHORS' CONTRIBUTIONS}

VYE and KA-N conceived the idea, analysed the data, fine-tune the draft and subsequent editing of the manuscript, whereas RBB collected the data and presented the first draft. All authors read the manuscript before submission.

\section{REFERENCES}

Agboyi LK, Djade KM, Ahadji-Dabla KM, Ketoh GK, Nuto Y, Glitho IA. 2015. Vegetable production in Togo and potential impact of pesticide use practices on the environment. Int. J. Biol. Chem. Sci., 9(2): 723-736. DOI: http:/dx.doi.org/10.4314/ijbcs.v9i2.13

Asghari MR, Hajitagilo R, Shirzad H. 2007. Postharvest treatment of salicylic acid effectively controls pear fruit diseases and disorders during cold storage. In: Proceedings of the International Congress on Novel Approaches for the Control of Postharvest Diseases and Disorders. Food and Agriculture COST action, 92: 355360.

Auger P, Guichou S, Kreiter S. 2003. Variations in acaricidal effect of wettable sulfur on Tetranychus urticae (Acari: Tetranychidae): Effect of temperature, humidity and life stage. Pest Manag. Sci 59(5):559-DOI: 10.1002/ps.665.

Cooper J, Dobson H. 2007. The benefits of pesticides to mankind and their environment. Crop Prot, 26: 1337-1348. DOI: $\quad 10,1016 /$ j.cropro.2007.03.022-1s2.0-S026121940700097X-main.pd

Curé G, Schmidt H.W, Schmuck R. 2001. Results of acomprehensive field research programme with the systemic insecticide imidacloprid (Gaucho®). In: Proceedings of the $7^{\text {th }}$ International Symposium "Hazards of pesticides to bees", September 7-9, 1999, Avignon, France (Belzunces LP, P Élissier C, Lewis GB. (Eds). Les Colloques de l'INRA, 98: 4959.

DARP. 2013. Database of Arthropods Resistance to Pesticides. www.pesticideresistance.org, Assessed 14/04/2015.

Eziah VY, Rose HA, Clift AD, Mansfield S. 2008. Susceptibility of four field populations of the diamondback moth Plutella xylostella L. (Lepidoptera: Yponomeutidae) to six insecticides in the Sydney region, New South Wales, Australia. Aus. J. Entomol., (4)7:355360 . DOI: $\quad 10.1111 /$ j. $1440-$ 6055.2008.00668.x

Fahnbulleh, CGV 2007. Acaricide resistance in Norwegian populations of the twospotted spider mite (Tetranychus urticae Koch) (Acari: Tetranychidae). M,sc thesis, Norwegien University of Life Science, p 59.

Gallo D, Nakano O, Neto SS, Carvalho RPL, Baptista GC, Filho EB, Parra JRP, Zucchi RA, Alves SB, Vendramin JD, Lopes JRS, Omoto C (2002) Entomologia Agrícola. Piracicaba, Editora Agronômica Ceres. P 920.

Ishaaya I. Konts E. Dalov S, Horowitz AR. 2002. Emamectin, a novel insecticide for 
controlling field crop pests. Pest Manag. Sci. 58: 1091-1095 DOI: 10.1002/ps.535

James DG, Price TS. 2002. Fecundity in twospotted spider mite (Acari: Tetranychidae) increased by direct and systemic exposure to Imidacloprid. $J$ Econ Entomol., 95(4): 729-732. DOI: http://dx.doi.org/10.1603/0022-049395.4.729

Kingsley BP. 2010. Susceptibility of Plutella xylostella (Lepidoptera: Plutellidae) to emamectin benzoate and lambdacyhalothrin in the greater Accra Region of Ghana. Mphil thesis, University of Ghana, p 124.

Mao L, Henderson G. 2007. Antifeedant activity and acute and residual toxicity of alkaloids from Sophora flavescens (Leguminosae) Against Formosan subterranean termites (Isoptera: Rhinotermitidae). J. Econ. Entomol., 100(3): $\quad 866-870 . \quad$ DOI: http://dx.doi.org/10.1093/jee/100.3.866

Marčić D, Međo I. 2014. Acaricidal activity and sublethal effects of an oxymatrinebased biopesticide on two-spotted spider mite (Acari: Tetranychidae). Exp. Appl. Acarol., 64: 375-391. DOI: 10.1007/s10493-014-9831-x

Osakabe MH, Uesugi R, Goka K. 2009. Evolutionary aspects of acaricideresistance development in spider mites. Psyche. 1-9. Article ID 947439. Available from: http://www.hindawi.com/ journals/psyche/2009/947439.html.[Cited 21 Feb 2015].

Owusu EO, Yeboah, PM. 2007. Status of cotton aphid, Aphis gossipii Glover (Homoptera: Aphididae) resistance to insecticides in Southern Ghana. Gh. J. Sci., 47: 107 - 115. DOI: http://dx.doi.org/10.4314/gjs.v47i1.15930

Park YL, Lee JH. 2002. Leaf cell and tissue damage of cucumber caused by twospotted spider mite (Acari:
Tetranychidae). J. Econ. Entomol., 95(5): 952-957.

DOI:http://dx.doi.org/10.1603/00220493-95.5.952

Pasay CJ, Arlian L, Morgan M, VyszenskiMoher D, Rose A. 2008. High-resolution melt analysis for the detection of a mutation associated with permethrin resistance in a population of scabies mites. Med. Vet. Entomol., 22: 82-88. DOI: $10.1111 / j .1365-2915.2008 .00716$

Piraneo TG. 2013. Acaricide resistance of the two-spotted spider mite (Tetranychus urticae) in Pacific Northwest hops. M.Sc thesis. Washington state University, p 67.

Piraneo TG, Bull J, Morales AM, Lavine CL, Walsh, Zhu F. 2015. Molecular mechanisms of Tetranychus urticae chemical adaptation in hop fields. Scientific Reports 5. DOI:10.1038/srep17090

Queiroz MC, Sato ME. 2016. Pyrethroid resistance in Phytoseiulus macropilis (Acari: Phytoseiidae): cross-resistance, stability and effect of synergists. Exp. Appl. Acarol., 68(1): 71-82. DOI: 10.1007/s10493-015-9984-2

Sato M, Silva M, Raga A, Filho M. 2005. Abamectin resistance in Tetranychus urticae Koch (Acari: Tetranychidae): selection, cross-resistance and stability of resistance. Neotrop. Entomol., 34: 991998. http://dx.doi.org/10.1590/S1519566X2005000600016

Sökeli E, Ay R, Karaca İ. 2007. Determination of the resistance level of two-spotted spider mite (Tetranychus urticae Koch) populations in apple orchards in Isparta Province against some pesticides. Tartm Bilimleri Dergisi-J. Agric. Sci., 13(4): 326-330.

Van Leeuwan TV, Dermauw W, Grbic M, Tirry L, Feyereisen R. 2012. Spider mite control and resistance management: does 
a genome help? Pest Manag. Sci., 69(2): 156-159. DOI: $10.1002 / p s .3335$

Van Leeuwan TV, Dermauw W, Tirry L, Vontas J, Tsagkarakou A. 2010. Acaricide resistance mechanisms in the two-spotted spider mite Tetranychus urticae and other important Acari. Insect Biochem. Molec., 40: 563-571.

Vassiliou VA, Kitsis P. 2013. Resistance in Tetranychus urticae (Acari: Tettranychidae) Populations from Cyprus. J. Econ. Entomol. 106(4): 1848-1854. DOI: http://dx.doi.org/10.1603/EC12369

Wang S, Wang R, Zhang Y, Xu B. 2009. Toxicity bioassay of 11 common acaricides to carmine spider mite,
Tetranychus cinnabarinus. Chin Agric Sci Bull, 25: 386-388.

Wintuma AS. 2009. Relationship between whitefly Bemisia tabaci (Gennadius) (Hemiptera: Aleyrodidae) susceptibility to insecticides and its associated carboxylesterase levels. M. Phil. thesis, University of Ghana. p 119.

Yang X, Buschman LL, Zhu KY, Margolies. 2002. Susceptibility and detoxifying enzyme activity in two spider mite species after selection with three insecticides. J. Econ. Entomol., 95(2): 399-406.

DOI: http://dx.doi.org/10.1603/0022-049395.2.399 